\title{
An Approach to Developing Local Climate Change Environmental Public Health Indicators in a Rural District
}

\author{
Adele Houghton, ${ }^{1}$ Jessica Austin, ${ }^{2}$ Abby Beerman, ${ }^{2}$ and Clayton Horton ${ }^{2}$ \\ ${ }^{1}$ Biositu, LLC, 505D W Alabama St., Houston, TX 77006, USA \\ ${ }^{2}$ Green River District Health Department, 1501 Breckenridge Street, Owensboro, KY 42303, USA
}

Correspondence should be addressed to Adele Houghton; adeleh@biositu.com

Received 10 September 2016; Revised 29 December 2016; Accepted 1 February 2017; Published 2 March 2017

Academic Editor: Pam R. Factor-Litvak

Copyright (C) 2017 Adele Houghton et al. This is an open access article distributed under the Creative Commons Attribution License, which permits unrestricted use, distribution, and reproduction in any medium, provided the original work is properly cited.

\begin{abstract}
Climate change represents a significant and growing threat to population health. Rural areas face unique challenges, such as high rates of vulnerable populations; economic uncertainty due to their reliance on industries that are vulnerable to climate change; less resilient infrastructure; and lower levels of access to community and emergency services than urban areas. This article fills a gap in public health practice by developing climate and health environmental public health indicators for a local public health department in a rural area. We adapted the National Environmental Public Health Tracking Network's framework for climate and health indicators to a seven-county health department in Western Kentucky. Using a three-step review process, we identified primary climate-related environmental public health hazards for the region (extreme heat, drought, and flooding) and a suite of related exposure, health outcome, population vulnerability, and environmental vulnerability indicators. Indicators that performed more poorly at the county level than at the state and national level were defined as "high vulnerability." Six to eight high vulnerability indicators were identified for each county. The local health department plans to use the results to enhance three key areas of existing services: epidemiology, public health preparedness, and community health assessment.
\end{abstract}

\section{Introduction}

Climate change represents a significant and growing threat to population health [1]. Health effects take the form of exacerbating existing, known hazards-such as increasing the risk of morbidity and mortality during heat waves [2] — and introducing novel health risks-such as Harmful Algal Blooms (HABs) erupting for the first time in warming waters [3].

Rural areas, comprising $95 \%$ of US landmass but housing only $19 \%$ of the population [4, p. 334], are particularly vulnerable to the health effects of climate change ([4, p. 339]; $[5,6])$. Natural climatic processes, such as airflow, often manifest differently in rural areas versus their urban counterparts. For example, ground level ozone, a key component of smog, is often associated with urban areas because motor vehicle exhaust is a major emitter of ozone precursors such as nitrogen oxide ( $\mathrm{NO} x$ ) [7]. However, rural areas can also experience high concentrations of ground level ozone when air currents transport the gas from the stratosphere or upper troposphere to the ground [8]. The meteorological shifts caused by climate change are likely to increase ozone events in both urban and rural areas, but via different mechanisms [9, pp. 72-73] that will require separate policy responses to be addressed.

Land use differences can also result in challenges that vary from rural to urban areas. For example, Culex mosquitoes, the primary vector for West Nile Virus, find the combination of vegetation and the drought/flooding cycle in rural areas an appealing habitat $[10$, p. 14], whereas, the Aedes aegypti mosquito, the primary vector for Dengue, Chikungunya, and Zika virus [11], prefers to live around residences in urban areas [12]. Both types of mosquitoes and the diseases they carry are highly responsive to changes in the climate. However, the vector control methods used to control them differ greatly.

Additionally, rural areas face different infrastructure challenges from urban areas, due to the low population density over large swathes of land. For example, during an extreme precipitation event, rural water basins can flood faster than 
urban areas; however, these areas often rely on low water crossings rather than bridges to cross water bodies, placing motorists at risk during flooding events. Furthermore, fewer alternate routes and transportation options are available in rural versus urban areas; and, rural communities often experience slower emergency response times than their urban neighbors [13, pp. 106-107]. After an event ends, it also can take longer to restore utilities to rural communities than to metropolitan regions [4].

Rural demographics include a disproportionate percentage of populations that have been shown to be vulnerable to climatic events. Rural populations tend to be older, less affluent, less well educated, and suffering from higher levels of unemployment than urban residents $[5,6]$. Of these demographic characteristics, elderly populations and families living in poverty have also been identified as populations who are particularly vulnerable to climatic events ([14-30]; [13, p. 108]). Population health status as a whole is often lower in rural areas than in urban areas, particularly in relation to chronic disease, in spite of rural residents' spending a higher proportion of their income on medical care than their urban counterparts [31]. Furthermore, the fragility of the rural built and emergency response infrastructure exacerbates the vulnerability of groups such as the elderly, families living in poverty, people of color, and populations with limited English proficiency, who have a higher likelihood of living in isolated rural areas [32, p. 252].

These demographic characteristics are often closely intertwined, due to a confluence of social, political, and economic structures collectively referred to as the social determinants of health. Rural populations representing a combination of high-risk social determinants of health (such as elderly populations living in poverty in a flood-prone area) can experience an amplification of the three elements comprising climate change vulnerability [32, p. 249] -increased exposure, increased sensitivity, and reduced adaptive capacityand should be prioritized for investment in both adaptation and emergency response interventions.

Finally, rural economies are more vulnerable to the negative effects of climate change because they rely on a combination of agriculture and heritage industries such as mining and heavy manufacturing [4, p. 335]. Many agricultural products are already facing climate-related challenges, such as shifting growing seasons and changing precipitation patterns, which will increase as the climate continues to change [33]. Agriculture and industry combined represented over $30 \%$ of US greenhouse gas (GHG) emissions in 2014, with the electric power industry (many of whose installations are located in rural areas) contributing an additional 30\% [34]. With 60\% of total US GHG emissions sourced from the economic engines of rural areas, these communities are particularly vulnerable to the negative economic consequences of GHG reduction policies. Additionally, agriculture is sensitive to changes in seasonal weather patterns $[35,36]$. On the other hand, mitigation activities such as reforestation and largescale renewable energy installations may reinvigorate some rural economies and hurt others [4, p. 340].

In spite of comprising the large majority of the nation's landmass and a sizeable minority of the country's population, less data is available quantifying the vulnerability of rural areas to climate-related environmental hazards than for urban areas, due to the challenges of developing robust statistical models in areas with low densities of both people and environmental sensors such as weather stations [37].

Local health departments are key players in protecting their communities from the negative health effects of climate change, both as participants in hazard mitigation planning and response [38] and as leaders in ongoing efforts to build resilience among vulnerable populations [39]. However, to date, fewer data sources and public health intervention opportunities are available for rural local health departments than for their urban counterparts [40]. The Third US National Climate Assessment identifies vulnerability assessments in rural areas as a key research gap [4, p. 340]. This need is particularly evident in the shortage of indicators measuring the health effects of specific climatic hazards in rural areas.

\subsection{Environmental Public Health Indicators. Environmental} public health indicators are a key component of vulnerability assessments. They are the building blocks for assessing a population's exposure and underlying vulnerabilities to environmentally related health threats such as climate change. They can also be used to track the success of policy and programmatic interventions aimed at reducing vulnerability. However, existing indicators often do not distinguish between rural and urban geographic areas-either aggregating to a larger geographic area (such as the state or county level) or not providing information for sparsely populated areas.

The National Environmental Public Health Tracking (EPHT) Program, hosted by the US Centers for Disease Control and Prevention (CDC), shares key vulnerability and health outcome environmental public health indicators at the national, state, and county levels for a wide array of environmental hazards, including climate change [41]. In 2014, Kentucky received a grant from the CDC to develop a statewide tracking program, EnviroHealthLink, based on the national framework [42]. The Green River District Health Department (GRDHD) conducted the project reviewed in this article under a grant from EnviroHealthLink. The project's goal was to reduce vulnerability to the negative health effects of climate change in a predominately rural region of Western Kentucky. Recognizing the resource and capacity constraints at a rural local health department, we set the objective of using existing online tools and datasets to bring an evidence-base to GRDHD activities relevant to climate change. To this end, we tailored EnviroHealthLink for use at the local level. Using the National EPHT online portal as a foundational resource for gathering datasets, we developed climate change environmental public health indicators relevant to the needs of a rural district. Our second objective was to identify opportunities for integrating the indicators into ongoing public health efforts, such as the community health assessment process and existing health surveillance programs. Our third objective was to identify opportunities for collaboration with partnering agencies, to ensure that vulnerable populations are prioritized in all resilience activities. 


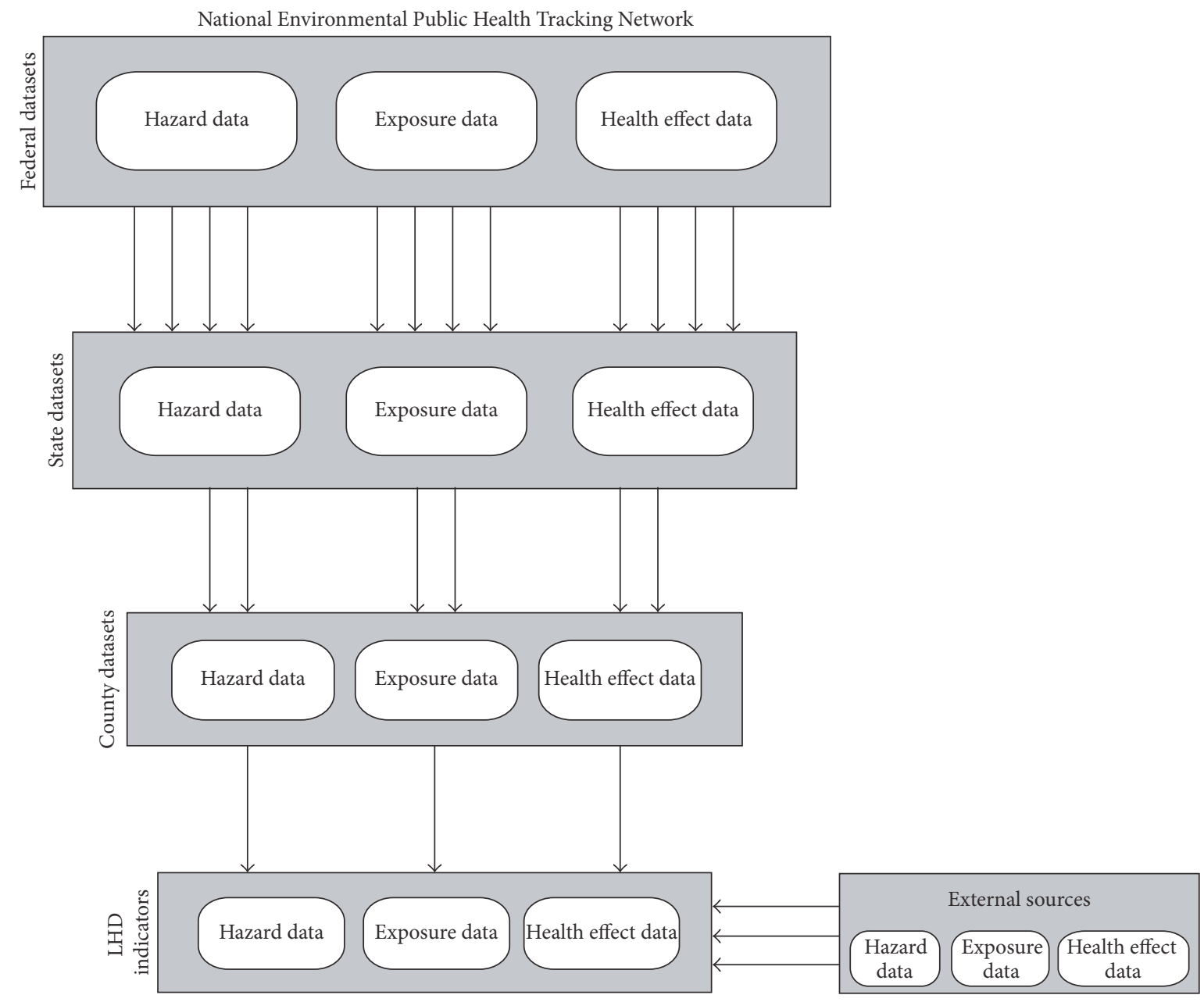

Figure 1: National EPHT Dataset Availability by Spatial Scale. Note. Adapted from the CDC's Environmental Public Health Tracking Program Conceptual Model, available at http://www.cdc.gov/nceh/tracking/pdfs/diagram.pdf.

\section{Materials and Methods}

\subsection{Applying the National Environmental Public Health Track-} ing Framework at the Local Level. The CDC's National EPHT Network was designed to compile data on environmental hazards, human exposure, and health effects into a single network of standardized databases. This framework enables researchers to evaluate relationships between datasets that historically have been difficult to review side by side [41] Data is currently available via an online portal at three spatial scales: federal, state, and county. While the majority of datasets are available at the federal level, the CDC funds 25 states (including Kentucky) and 1 city to assist in compiling and making public the smaller spatial scales [43]. Fewer datasets are available at the county level than at the state and federal levels (Figure 1), presenting a challenge to local health departments using the National EPHT Network to support evidence-based policies and programs. The framework presented in this article (Figure 1) recognizes the need to supplement National EPHT datasets with external sources for two purposes: (a) to assess a community's vulnerability to the health effects of climate change and (b) to establish metrics for evaluating the success of local climate and health policies.

2.2. Selecting Environmental Hazards for Indicator Development. The Green River District (GRD) is comprised of seven counties in Western Kentucky: Daviess, Hancock, Henderson, McLean, Ohio, Webster, and Union. It is a predominantly rural area, with two major population centers, Owensboro and Henderson. Total population in 2014 fell just shy of 215,300 residents [44]. All seven counties in the district have a higher percentage of rural residents than the national average (19.3\%); and five of the seven exceed the Kentucky average of $41 \%$ (Figure 2). The diversity in land use represented across the district, particularly comparing the two more urban counties (Daviess and Henderson) with the five fully rural counties, presents an opportunity to assess the unique challenges and opportunities facing rural health districts engaged in protecting their populations from the negative health effects of climate change.

We used a three-step review process adapted from the CDC's Building Resilience Against Climate Effects (BRACE) 


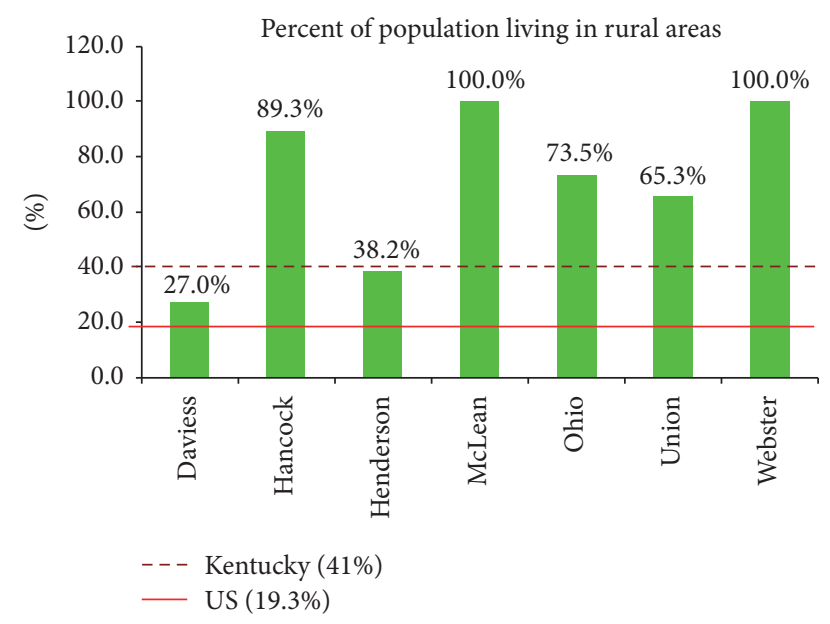

FIgURE 2: Percentage population classified as rural, by county (KY/GRD: 2016, US: 2010). Sources. KY/GRD (2016): County Health Rankings, http://www.countyhealthrankings.org. US (2010): US Census Bureau, Population Division, http://www.census.gov.

framework to identify which climate-related hazards should be developed into environmental public health indicators for the GRDHD. The BRACE framework is a five-step approach to informing public health adaptation efforts at the state and local levels. The five steps are as follows: (1) Anticipating Climate Impacts and Assessing Vulnerabilities; (2) Projecting the Disease Burden; (3) Assessing Public Health Interventions; (4) Developing and Implementing a Climate and Health Adaptation Plan; and (5) Evaluating Impact and Improving Quality of Activities [45]. The GRDHD project completed a portion of Step (1): Anticipating Climate Impacts and Assessing Vulnerabilities.

First, we reviewed the Third National Climate Assessment [46] and the associated scientific assessment of the impacts of climate change on human health [40] to develop a short list of climate-related environmental hazards with a history and/or projected future of risk to human health in the Southeastern US. We then gathered evidence at a more granular level [47-50] to identify which hazards were associated with the most negative health outcomes and highest economic burdens in rural Western Kentucky. Finally, we consulted with climatologists, emergency management officials, and other subject matter experts at the local and state levels to validate our selection of extreme heat, drought, and flooding as the leading climate-related hazards for the region.

2.2.1. Extreme Heat. As temperatures rise due to the buildup of GHG in the Earth's atmosphere, regions such as Western Kentucky can expect to see increases in both average annual temperatures and the number of extreme heat days each year. By 2050, the average annual temperature in the Green River District is projected to increase from close to $4^{\circ} \mathrm{F}$ (under a low emissions scenario) to $5^{\circ} \mathrm{F}$ (under a high emission scenario) [47, p. 15]. By 2020-2039, Kentucky as a whole is projected to experience up to 23 days per year with temperatures exceeding $95^{\circ} \mathrm{F}$. From 2040 to 2059 , up to 44 days per year could exceed $95^{\circ} \mathrm{F}$. Western Kentucky is projected to warm more than other regions in the commonwealth [51, pp. 44-45].

Given these projections and in consultation with the state climatologist, we defined extreme heat exposure as three or more days with maximum temperatures greater than or equal to 95 degrees.

Exposure to extreme heat can inhibit the body's natural ability to regulate its internal temperature. It can also exacerbate cardiovascular, respiratory, and cerebrovascular diseases [52, p. 46]. Heat combined with humidity and extended exposure to extreme heat alone can be debilitating, reducing an individual's ability to concentrate and leading to fatigue ([52, p. 46]; [53, 54]). From a mental health perspective, extreme heat has been linked with increases in aggressive behavior and hospital admittances for psychiatric conditions $[53,55,56]$. The combination of heat and humidity may also correlate with increases in suicide rates, although current findings are not conclusive $[53,54]$.

Population vulnerability to extreme heat includes individuals on either end of the age spectrum. Both children and the elderly have a limited capacity to regulate their internal temperature [14]. Both groups are also likely to rely on others to keep them safe during heat events $[15-19,57]$. Families living in poverty are at risk, because they may not have sufficient access to heat-related adaptations such as weatherized buildings and affordable air conditioning [15, 17, 18, 20-22]. NonHispanic Black populations are often at higher risk than the general population because of a combination of health status, socioeconomic status, and environmental justice concerns $[15,17,18,21,23-25,58]$. Homeless populations may combine increased exposure to heat and cold with other risk factors such as social isolation, psychiatric illness, and multiple chronic diseases [59]. Outdoor workers are at increased risk of negative health outcomes during extreme heat events, due to increased exposure to elevated temperatures during the heat of the day $[19,60,61]$.

Preexisting chronic health conditions can also place an individual at higher risk of negative health outcomes during an extreme heat event. For example, obese individuals are more sensitive to high ambient temperatures [3, p. 34]. Similarly, exposure to heat can exacerbate conditions such as diabetes, cardiovascular disease, asthma, and cerebrovascular disease [52, p. 46].

2.2.2. Drought. Kentucky has experienced a trend of increasing drought conditions since the 1950s [62]. As temperatures warm and precipitation patterns become less reliable, these events are likely to increase in frequency ([47, pp. 13-14 and Figure 4]; $[63,64])$. According to Climate Central, the severity of summertime droughts in Kentucky is expected to double by 2050 [65].

We defined exposure to drought as a severe (D2), extreme (D3), or exceptional (D4) drought declaration by the US Drought Monitor.

It can be difficult to quantify the direct health effects of drought, because they tend to result from a complex interplay of socioeconomic variables (such as loss of livelihood); local environmental characteristics (such as land use patterns); and interactions between the drought and other related natural 
events (such as the prevalence of wildfires or the duration of a heat wave) $[66,67]$. As a result, we did not develop direct health outcomes for this hazard. However, exposure to fine particulate matter (in the form of dust) could be used as a proxy for the health effects of drought associated with poor air quality.

The population vulnerability indicators associated with drought overlap with extreme heat, in part, because the two hazards can occur concurrently. Children and the elderly are particularly vulnerable to the effects that drought can have on air quality and water quality [23, 24, 26-28, 68-72]. Similarly, individuals with diabetes, chronic lower respiratory disease (CLRD), and asthma are at heightened risk due to their sensitivity to poor air quality $[26-28,73]$. Finally, rural areas have been associated with more severe mental health concerns (such as anxiety, depression, and posttraumatic stress disorder (PTSD)) during droughts than urban areas, due to the strong economic relationship between precipitation and agricultural yields $[66,74-77]$. Social networks in rural areas can be disrupted when populations relocate during a drought to seek alternative employment [53, 54, 66, 74-77]. This vulnerability is compounded by the difficulty of accessing mental health services in many rural communities ([4, p. 339]; [54]).

2.2.3. Flooding. Major disasters were declared in Kentucky due to flooding and/or severe storms 29 times from 20002015, damaging 6,000 homes-many of which belonged to low-income families. The number of declarations over that fifteen-year period is almost equivalent to the previous forty years combined [78]. Western Kentucky has historically experienced 55 thunderstorm days per year [79], with the 30-year average of total annual precipitation slowly trending upwards starting in the 1960s and a more marked rise (particularly during spring months) from the 1990s onward [80]. Average annual precipitation in the GRD is projected to increase $2 \%$ under a low emissions scenario and up to $6 \%$ under a high emissions scenario [47, p. 16].

We defined exposure to flooding as the number of days annually with precipitation over 2 inches, as reported by weather stations.

The health effects of flooding range from drowningrelated injury and death [24, 81-86] to gastrointestinal illnesses $[24,85]$ and mental health concerns $[24,54,85,86]$. Other flooding-related morbidities and mortalities are more difficult to track, because flooding may not be listed as a primary cause in the diagnosis or on the death certificate [13, p. 114]. However, it can be extrapolated in some cases. For example, poor indoor air quality arising from dampness and mold in the home is currently associated with $8 \%-20 \%$ of respiratory infections in the US (such as acute bronchitis) and with exacerbating 4.6 million cases of asthma [87, 88]. Flooding events can also result in power outages, which have been associated with carbon monoxide poisoning caused by using combustion appliances indoors [89, 90].

Similar to extreme heat and drought, children and the elderly are particularly vulnerable to negative health outcomes after exposure to flooding. Both groups are more vulnerable than the population as a whole to flooding-related injuries and illnesses [24, 25]. Children are particularly vulnerable if they are separated from their caregivers [9193]. Both populations are also particularly susceptible to the negative mental health effects of flooding ([13, p. 108]; [54]) associated with the loss of property and loved ones, economic hardship, and dislocation. These health outcomes include anxiety, PTSD, aggression in children, and suicidal tendencies $[24,53,85,86]$. The dangers associated with medical disruptions also led to the inclusion of long-term care facilities $[24,29,30,94-99]$ and diabetes $[100,101]$ on the list of vulnerability indicators for the GRD.

2.3. Populating Baseline Environmental Public Health Indicators at the Local Level. To assess the Green River District's relative vulnerability to each hazard, we compiled environmental exposure, human health outcome, population vulnerability, and environmental vulnerability indicators drawn from the literature review for each hazard. Table 1 illustrates that while a number of key indicators were available on the National EPHT Network portal (most notably, environmental exposure indicators) external sources were required to perform a comprehensive assessment at the local level. For example, a number of studies have established a correlation between extreme heat events and heat-related morbidity and/or mortality by comparing the dates of extreme heat events with the dates of heat-related morbidity and mortality data [102-105]. While the National EPHT portal provides heat-related mortality data for Kentucky during summer months from 1999 to 2014, it does not provide data at the county level. Furthermore, the datasets are annualized to protect privacy [106]. However, county-level temperature data from 2000 to 2012 (also obtained from the National EPHT portal) shows geographic variation across the district [106]. This variation is likely even more pronounced across the commonwealth. In order to compare morbidity and mortality data with the actual dates meeting the definition of an extreme heat event, we gathered heat exposure data from the Kentucky Climate Center and heat-related morbidity and mortality data from the Kentucky Department for Public Health. The Kentucky Injury Prevention and Research Center at the University of Kentucky retrieved the health data from the Kentucky Inpatient Hospitalization and Outpatient Services Claims Files at the Kentucky Cabinet for Health and Family Services, Office of Health Policy, and from the Kentucky Death Certificates Files at the Kentucky Department for Public Health, Cabinet for Health and Family Services. It received Institutional Review Board approval from the Kentucky Cabinet for Health and Family Services.

Similarly, while robust, the population and environmental vulnerability data available on the National EPHT portal are not as comprehensive as the list of correlations in the public health literature. It was therefore necessary to gather a number of local level datasets from sources such as the US Census, CDC databases outside of the EPHT program, and the Kentucky Department for Public Health (Table 1). Attempts to gather local level mental health data were unsuccessful. Comprehensive mental health data is lacking for most of the identified region. 
TABLE 1: Availability of Green River District climate and health indicator datasets from the EPHT Network, external sources.

\begin{tabular}{ll}
$\begin{array}{l}\text { Indicator } \\
\text { category }\end{array}$ & $\begin{array}{l}\text { Data available from EPHT Network } \\
\text { (notes) }\end{array}$ \\
\hline $\begin{array}{l}\text { Environmental } \\
\text { exposure }\end{array}$ & $\begin{array}{l}\text { Exposure to heat waves }{ }^{\mathrm{h}} \\
\text { Exposure to heavy precipitation events }{ }^{\mathrm{f}} \\
\text { Exposure to air pollution }\end{array}$ \\
\hline & \\
& \\
$\begin{array}{l}\text { Human health } \\
\text { outcome }\end{array}$ & $\begin{array}{l}\text { Heat-related mortality during summer months } \\
\text { (annualized data; not available at county level) }\end{array}$
\end{tabular}

Data from external source

(source)

Exposure to heat waves ${ }^{\mathrm{h}}$

(Kentucky Climate Center)

Exposure to drought ${ }^{\mathrm{d}}$

(US Drought Monitor)

Exposure to air pollution $^{\mathrm{d}}$

(CDC WONDER)

Exposure to heavy precipitation events ${ }^{\mathrm{f}}$

(Kentucky Climate Center, National Weather Service)

Heat-related morbidity and mortality during extreme heat events ${ }^{\mathrm{h}}$

(Kentucky Cabinet for Health and Family Services, Office of Health

Policy; Kentucky Department for Public Health, Cabinet for Health and Family Services)

Unintentional flooding-related mortality during flooding events ${ }^{\mathrm{f}}$

(Kentucky Department for Public Health, Cabinet for Health and

Family Services, CDC WONDER)

Unintentional flooding-related morbidity during flooding events ${ }^{\mathrm{f}}$

(Kentucky Cabinet for Health and Family Services, Office of Health

Policy; Kentucky Department for Public Health, Cabinet for Health and Family Services)

Children $^{\text {h,d,f }}$, elderly ${ }^{\text {h,d,f }}$, population living in poverty ${ }^{\text {h,f }}$,

non-Hispanic Blacks ${ }^{\mathrm{h}, \mathrm{d}, \mathrm{f}}$, outdoor workers ${ }^{\mathrm{h}}$, population with limited

English proficiency ${ }^{\mathrm{f}}$, ambulatory difficulty ${ }^{\mathrm{f}}$ (US Census)

Homeless $^{\mathrm{h}}$

(Kentucky Housing Corporation, US Housing and Urban

Asthma $^{\text {h,d }}$

Diabetes $^{\text {h,d,f }}$

Heart disease ${ }^{\mathrm{h}}$ vulnerability
Population (not available at county level)

Obesity $^{\mathrm{h}}$

(not available at county level)

Poverty ${ }^{\mathrm{h}, \mathrm{f}}$

(not available at county level)
Development)

Long-term Care

(Kentucky Cabinet for Health and Family Services Office of Health

Policy)

Chronic lower respiratory Disease ${ }^{\mathrm{d}}$

(CDC Community Health Status Indicators)

Diabetes $^{\text {h,d,f }}$

(Kentucky Behavioral Risk Factor Surveillance System)

Heart disease $^{\mathrm{h}}$, cerebrovascular disease ${ }^{\mathrm{h}}$

(CDC Interactive Atlas of Heart Disease and Stroke)

Mental health ${ }^{\mathrm{d}, \mathrm{f}}$

(Kentucky Safety and Prevention Alignment Network)

Obesity $^{\text {h }}$

(CDC Behavioral Risk Factor Surveillance System)

Air conditioning access ${ }^{\mathrm{h}}$

(Energy Information Administration Residential Energy Consumption Survey)

Carbon monoxide poisoning ${ }^{\mathrm{h}, \mathrm{f}}$

Environmental $\quad$ Carbon monoxide poisoning ${ }^{\mathrm{h}, \mathrm{f}}$

(KY data currently not available via EPHT portal)

(Kentucky Cabinet for Health and Family Services)

Stressed housing ${ }^{\mathrm{h}, \mathrm{d}, \mathrm{f}}$

(CDC Community Health Status Indicators)

Notes.

${ }^{\mathrm{h}}$ Heat indicator

${ }^{\mathrm{d}}$ Drought indicator.

${ }^{\mathrm{f}}$ Flooding indicator

The project's short timeline, limited funding, and capacity constraints precluded the use of statistical analysis to identify the subset of indicators that were most relevant to each county or the region as a whole. The project report recommends filling this gap under the next round of funding. Given this constraint, which is not uncommon at local health departments, we directly compared each local indicator with parallel Kentucky and US datasets, if available, to establish a rough understanding of which indicators might prove to be outliers using more sophisticated methods of analysis. Five indicators 
were also compared with federal standards: exposure to air pollution (compared with US EPA 2012 annual standard for fine particulate matter concentrations [107]), obesity (compared with Healthy People 2020 Goal NWS-9 [108]), heart disease mortality (compared with Healthy People 2020 Goal HDS-2 [109]), asthma hospitalizations (compared with Healthy People 2020 Goal RD-2.2 [110]), and cerebrovascular deaths (compared with Healthy People 2020 Goal HDS-3 [109]). Indicators were defined as high vulnerability if they fell short of both Kentucky and US indicators. They were defined as moderate if they fell in between the larger-scale indicators. And they were defined as low if they represented an improvement over both the Kentucky and US indicators.

\section{Results}

3.1. Rural Vulnerabilities of the Green River District. The Green River District demonstrates high risk for two of the key vulnerable populations characteristic of rural areas, as identified in the scientific literature: the elderly and families living in poverty (Table 2). All seven counties in the district host a slightly higher proportion of elderly populations (aged $65+$ ) than the national average or the commonwealth of Kentucky. Every county except for Hancock also exceeds the national proportion of populations living in poverty. However, only Ohio County also exceeds both the national and Kentucky average.

Of the chronic diseases that can increase vulnerability to the negative health effects of extreme heat, drought, and flooding, many of the counties in the Green River District report higher levels of diabetes, heart disease, CLRD, asthma, and cerebrovascular disease than both Kentucky and the US as a whole (Table 2). Due to a lack of baseline data for the GRD region, comparisons between county mental health status and state and national standards are not shown.

3.2. Extreme Heat Vulnerability. Table 3 displays the dates from 2000 to 2012 when one or more county in the district met the project's extreme heat exposure definition. Interestingly, two of the most rural counties in the district (Union and Webster) experienced the highest number of extreme heat events over this time period. Union County also displayed the highest rate of heat-related emergency department visits in the district from 2008 to 2012 (Figure 3).

The elderly were identified in all seven counties as a population with high vulnerability. Children were similarly identified for five counties, excluding Union and Webster. Homeless populations were identified as highly vulnerable in Daviess, the most urban county in the district. In contrast, outdoor workers were identified as a high vulnerability population in the five particularly rural counties-Hancock, McLean, Ohio, Union, and Webster. Obesity and/or diabetes and heart disease were also identified as indicators of high vulnerability to extreme heat in the same five counties (Table 2).

3.3. Drought Vulnerability. From 2007 to 2012, the district experienced three widespread droughts meeting the project's definition: August-October 2007, October-December 2010,

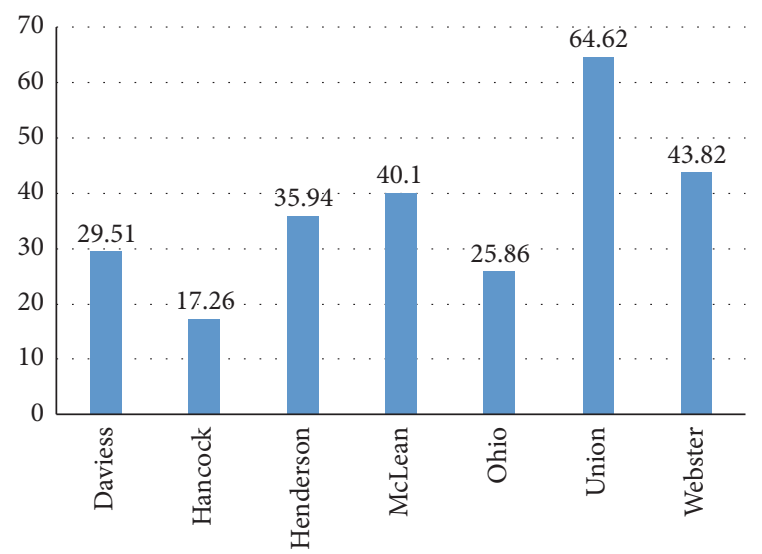

FIGURE 3: Heat-related emergency department visits per 10,000 by county (2008-2012). Source. Kentucky Inpatient Hospitalization and Outpatient Services Claims Files at the Kentucky Cabinet for Health and Family Services, Office of Health Policy. Retrieved by the Kentucky Injury Prevention and Research Center at the University of Kentucky.

and May-October 2012 (Figure 4). Furthermore, the most intensive drought, July-August 2012, coincided with 33 days of extreme heat exposure (Table 3). During those two months, exceptional drought (D4) was declared in five of the seven counties, demonstrating the complex interplay between climate-related hazards such as extreme heat and drought.

The average concentration of $\mathrm{PM}_{2.5}$ in the Green River District $\left(14.1 \mathrm{PM}_{2.5} \mu \mathrm{g} / \mathrm{m}^{3}\right)$ was slightly higher than the Kentucky average $\left(13.5 \mathrm{PM}_{2.5} \mu \mathrm{g} / \mathrm{m}^{3}\right)$ in 2011 and significantly higher than the national average of the same year (11.1 $\mathrm{PM}_{2.5} \mu \mathrm{g} / \mathrm{m}^{3}$ nationally) [111].

The demographic picture for high vulnerability drought indicators in the Green River District aligns with extreme heat regarding children and the elderly. Daviess County again stands out from the rest of the region by identifying a subpopulation as highly vulnerable that is not picked up in the other six counties: individuals requiring mental health services. Diabetes is identified as a high vulnerability indicator in the rest of the region, along with CLRD and/or asthma in Hancock, Henderson, and Webster Counties (Table 2).

3.4. Flood Vulnerability. Flooding and severe thunderstorms accounted for $42 \%$ of natural hazard events and $92 \%$ of related property damage in the Green River District from 2010 to 2015 [48, Figures 4-1 and 4-2] with serious flooding occurring, on average, every two years [48, p. 109]. The entire GRD averaged at least 15 days of high water flow annually from 2000 to 2009, with some areas experiencing 23 days or more [112]. Figure 5 displays the number of flooding events in the district reported in the NOAA National Climatic Data Center Storm Events Database from 2000 to 2015. During the same period, the direct economic effects of flooding in the area reached close to $\$ 40$ million in property damage and $\$ 6$ million in crop damage [50].

Residents of the GRD are highly vulnerable to flooding, in part, due to development in known floodplains. The FEMA 
TABLE 2: High vulnerability by climate hazard in Green River District counties.

\begin{tabular}{|c|c|c|c|c|}
\hline County & Indicators with high vulnerability & Extreme heat & Drought & Flooding \\
\hline \multirow{6}{*}{ Daviess } & Children & $\checkmark$ & $\checkmark$ & $\checkmark$ \\
\hline & Elderly & $\checkmark$ & $\checkmark$ & $\checkmark$ \\
\hline & Homeless & $\checkmark$ & & \\
\hline & Mental health & & $\checkmark$ & $\checkmark$ \\
\hline & Long-term care & & & $\checkmark$ \\
\hline & FEMA floodplain & & & $\checkmark$ \\
\hline \multirow{8}{*}{ Hancock } & Children & $\checkmark$ & $\checkmark$ & $\checkmark$ \\
\hline & Elderly & $\checkmark$ & $\checkmark$ & $\checkmark$ \\
\hline & Outdoor workers & $\checkmark$ & & \\
\hline & Diabetes & $\checkmark$ & $\checkmark$ & $\checkmark$ \\
\hline & Heart disease & $\checkmark$ & & \\
\hline & CLRD & & $\checkmark$ & \\
\hline & Long-term care & & & $\checkmark$ \\
\hline & FEMA floodplain & & & $\checkmark$ \\
\hline \multirow{8}{*}{ Henderson } & Children & $\checkmark$ & $\checkmark$ & $\checkmark$ \\
\hline & Elderly & $\checkmark$ & $\checkmark$ & $\checkmark$ \\
\hline & Diabetes & $\checkmark$ & $\checkmark$ & $\checkmark$ \\
\hline & CLRD & & $\checkmark$ & \\
\hline & Asthma & $\checkmark$ & $\checkmark$ & \\
\hline & Cerebrovascular disease & $\checkmark$ & & \\
\hline & FEMA floodplain & & & $\checkmark$ \\
\hline & Stressed housing & $\checkmark$ & $\checkmark$ & $\checkmark$ \\
\hline \multirow{8}{*}{ McLean } & Children & $\checkmark$ & $\checkmark$ & $\checkmark$ \\
\hline & Elderly & $\checkmark$ & $\checkmark$ & $\checkmark$ \\
\hline & Outdoor workers & $\checkmark$ & & \\
\hline & Diabetes & $\checkmark$ & $\checkmark$ & $\checkmark$ \\
\hline & Heart disease & $\checkmark$ & & \\
\hline & Cerebrovascular disease & $\checkmark$ & & \\
\hline & Long-term care & & & $\checkmark$ \\
\hline & FEMA floodplain & & & $\checkmark$ \\
\hline \multirow{8}{*}{ Ohio } & Children & $\checkmark$ & $\checkmark$ & $\checkmark$ \\
\hline & Elderly & $\checkmark$ & $\checkmark$ & $\checkmark$ \\
\hline & Poverty & $\checkmark$ & $\checkmark$ & $\checkmark$ \\
\hline & Outdoor workers & $\checkmark$ & & \\
\hline & Diabetes & $\checkmark$ & $\checkmark$ & $\checkmark$ \\
\hline & Heart disease & $\checkmark$ & & \\
\hline & Long-term care & & & $\checkmark$ \\
\hline & FEMA floodplain & & & $\checkmark$ \\
\hline \multirow{6}{*}{ Union } & Elderly & $\checkmark$ & $\checkmark$ & $\checkmark$ \\
\hline & Outdoor workers & $\checkmark$ & & \\
\hline & Obesity & $\checkmark$ & & \\
\hline & Heart disease & $\checkmark$ & & \\
\hline & Cerebrovascular disease & $\checkmark$ & & \\
\hline & FEMA floodplain & & & $\checkmark$ \\
\hline \multirow{8}{*}{ Webster } & Elderly & $\checkmark$ & $\checkmark$ & $\checkmark$ \\
\hline & Outdoor workers & $\checkmark$ & & \\
\hline & Obesity & $\checkmark$ & & \\
\hline & Diabetes & $\checkmark$ & $\checkmark$ & $\checkmark$ \\
\hline & Heart disease & $\checkmark$ & & \\
\hline & CLRD & & $\checkmark$ & \\
\hline & Asthma & $\checkmark$ & $\checkmark$ & \\
\hline & Cerebrovascular disease & $\checkmark$ & & \\
\hline
\end{tabular}


TABLE 3: Extreme heat exposure in Green River District County (2000-2012): days with maximum temperatures greater than or equal to 95 degrees from May to September.

\begin{tabular}{|c|c|c|}
\hline Years & Extreme heat exposure & Counties affected \\
\hline 2000 & $8 / 28 / 00-8 / 30 / 00$ & Union, Webster \\
\hline 2001 & No dates met exposure definition & \\
\hline \multirow{2}{*}{2002} & $8 / 02 / 02-8 / 04 / 02$ & Union \\
\hline & $9 / 07 / 02-9 / 10 / 02$ & Henderson, Union, and Webster \\
\hline 2003 & No dates met exposure definition & \\
\hline 2004 & No dates met exposure definition & \\
\hline \multirow{2}{*}{2005} & $7 / 24 / 05-7 / 26 / 05$ & Union \\
\hline & $8 / 09 / 05-8 / 14 / 05$ & Henderson, McLean, Union, and Webster \\
\hline \multirow{3}{*}{2006} & $7 / 18 / 06-7 / 21 / 06$ & Union \\
\hline & $7 / 30 / 06-8 / 03 / 06$ & Union, Webster \\
\hline & $8 / 06 / 06-8 / 10 / 06$ & Union \\
\hline \multirow{3}{*}{2007} & $7 / 31 / 07-8 / 24 / 07$ & All counties \\
\hline & $8 / 27 / 07-8 / 29 / 07^{*}$ & Henderson, McLean, Union, and Webster \\
\hline & $9 / 02 / 07-9 / 05 / 07^{*}$ & $\begin{array}{c}\text { Daviess, Henderson, McLean, Union, and } \\
\text { Webster }\end{array}$ \\
\hline 2008 & No dates met exposure definition & \\
\hline 2009 & No dates met exposure definition & \\
\hline 2010 & $\begin{array}{c}/ 23 / 10-7 / 25 / 10^{*} \\
8 / 01 / 10-8 / 04 / 10 \\
8 / 08 / 10-8 / 15 / 10 \\
8 / 19 / 10-8 / 22 / 10 \\
8 / 31 / 10-9 / 02 / 10 \\
9 / 19 / 10-9 / 23 / 10 \\
\end{array}$ & $\begin{array}{l}\text { Hancock } \\
\text { All counties } \\
\text { All counties } \\
\text { All counties } \\
\text { All counties } \\
\text { All counties }\end{array}$ \\
\hline 2011 & $8 / 31 / 11-9 / 03 / 11$ & All counties \\
\hline \multirow{6}{*}{2012} & $6 / 18 / 12-6 / 21 / 12$ & Henderson, McLean, Union, and Webster \\
\hline & $6 / 23 / 12-6 / 25 / 12$ & Henderson, McLean, and Webster \\
\hline & $6 / 27 / 12-7 / 10 / 12$ & All counties \\
\hline & $7 / 15 / 12-8 / 09 / 12$ & All counties \\
\hline & $8 / 23 / 12-8 / 25 / 12^{*}$ & $\begin{array}{c}\text { Daviess, Henderson, McLean, Union, and } \\
\text { Webster }\end{array}$ \\
\hline & $8 / 28 / 12-8 / 31 / 12^{* *}$ & All counties \\
\hline
\end{tabular}

Notes.

*All other counties reached threshold for 2 days.

${ }^{* *}$ Hancock County reached one-degree shy-of-threshold on 8/29/12.

Source. National Environmental Public Health Tracking Program, http://ephtracking.cdc.gov/.

floodplain was listed as a high vulnerability indicator for all counties in the district except for Webster County, because they exceed the Kentucky (5.4\%) percentage of populations living in the 100-year floodplain (Table 2). Three countiesDaviess (13.6\%), Hancock (14.7\%), and McLean (12.8\%)demonstrate more than double the average statewide exposure [106]. From a geographic perspective, every county except Webster also greatly exceeds the percentage of Kentucky $(9.8 \%)$ land located in a floodplain, with close to onehalf of the land in Henderson (43.2\%) and McLean (45.3\%) counties located in vulnerable areas [106]. In spite of the relatively high percentage of residents in the district living in a floodplain, less than $2 \%$ hold current flood insurance policies
[113], further increasing their vulnerability to the economic effects of flooding.

The district experienced 7 unintentional drowningrelated mortalities from 2008 to 2015 [114]. From 2008 to 2013, emergency department visits in the Green River District related to carbon monoxide poisoning ranged from 11 in Union and Webster Counties to 36 in Daviess County [115].

Similar to drought, mental health concerns were only identified as a high vulnerability indicator for flooding exposure in the more urban Daviess County. Patients in long-term care facilities were identified as an indicator with high vulnerability in Daviess, Hancock, McLean, and Ohio counties. And diabetes was identified as a high vulnerability 


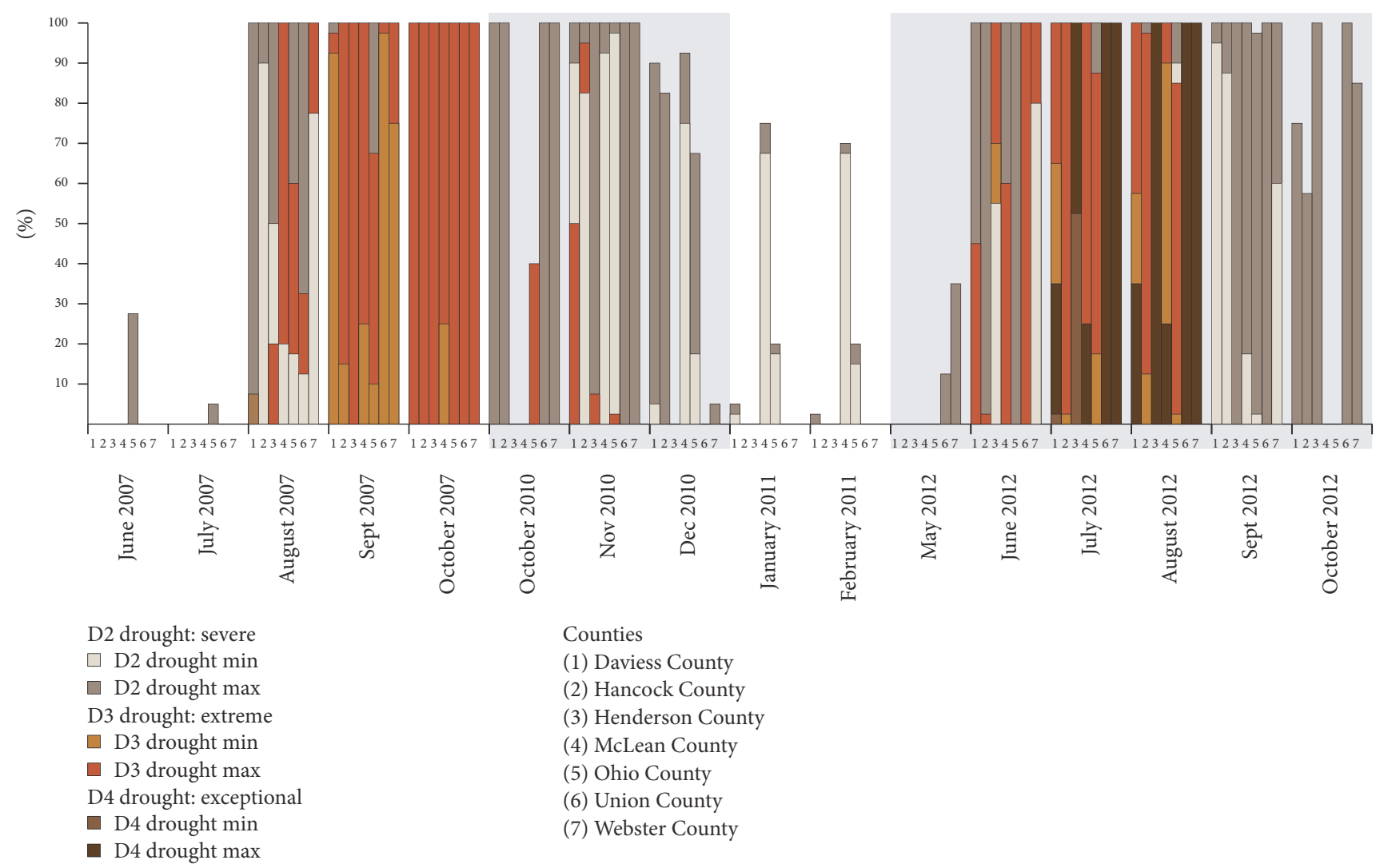

Figure 4: Percent population impacted by drought in Green River District counties (2007-2012). Source. US Drought Monitor, http:// droughtmonitor.unl.edu/Home.aspx.

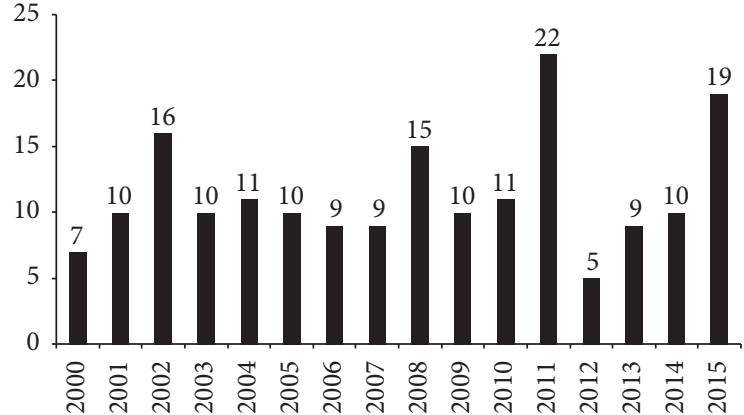

FIGURE 5: Number of flooding events in Green River District by year (2000-2015). Source. NOAA National Climatic Data Center Storm Events Database, http://www.ncdc.noaa.gov/stormevents.

indicator in five of the seven counties: Hancock, Henderson, McLean, Ohio, and Webster (Table 2).

\section{Discussion}

Comparing the baseline climate change environmental public health indicators for the Green River District, Daviess County's more urban status distinguished it from the other six counties, particularly in terms of the need to develop educational messaging and services for homeless populations. Baseline indicators for the more rural counties, on the other hand, included an emphasis on outdoor workers and populations with existing chronic conditions such as diabetes, heart disease, and asthma. These differences indicate that climate and health policies and interventions in the Green River District must distinguish between the needs of rural and urban populations in the seven-county region.

While current policies and programs in the GRDHD do not explicitly address climate change, three areas of current engagement are particularly relevant to the study results described above: epidemiology, public health preparedness, and community health assessment.

Initial research highlighted mental health awareness as a major weakness in the GRD region. Due to the lack of focus on mental health within current programs and data collection, GRDHD will be considering the status of mental health conditions, the rural impact on mental health services and access, and environmental influences on mental health for future grants and programs.

The GRDHD epidemiology program monitors the health status of the community and investigates disease clusters and outbreaks. A passive surveillance system is already in place, tracking infectious diseases reported by health care providers and other community members. Several reportable conditions are relevant to climate and health surveillance, such as mosquito-borne diseases (West Nile Virus, Zika 
TABLE 4: Green River District Health Department proposed climate and health surveillance system.

\begin{tabular}{lll}
\hline Hazard & $\begin{array}{l}\text { Exposure indicator } \\
\text { (surveillance trigger) }\end{array}$ & Reportable health outcome \\
\hline Extreme heat & $\begin{array}{l}\text { Max temperature greater than or equal to 95 } \\
\text { for a minimum of 3 days } \\
\text { (Heat advisory issued by National Weather } \\
\text { Service) }\end{array}$ & $\begin{array}{l}\text { Number of heat-related deaths (ICD-10: X30); } \\
\text { number of heat stress hospitalizations and } \\
\text { emergency department visits (ICD-9: 992, E900.0, } \\
\text { E900.9) from May to September. }\end{array}$ \\
\hline & $\begin{array}{l}\text { County declared in D2 (severe), D3 } \\
\text { (extreme), or D4 (exceptional) drought by } \\
\text { US Drought Monitor } \\
\text { (Same) }\end{array}$ & In development. \\
\hline Number of days with precipitation over 2 \\
inches reported by weather stations annually \\
Flooding
\end{tabular}

Virus, etc.) and waterborne disease outbreaks [116]. The epidemiology department also provides morbidity and mortality surveillance to the state health department during community outbreaks and disasters. Based on the results of this study, the GRDHD plans on expanding both the surveillance and reporting arms of the epidemiology department to track environmental exposure indicators for all three climate hazards and reportable health outcomes for extreme heat and flooding (Table 4). Future work may include correlating health outcome data with the dates when extreme heat or flooding events occurred, in order to validate or change the thresholds established during this project to trigger heat-, drought-, and flooding-related surveillance activities, public education campaigns, and interventions such as opening cooling centers and emergency shelters.

The health department supports local emergency preparedness agencies to safeguard the health of vulnerable populations during and after both natural and human-caused disasters. Much of this work involves public communicationexplaining the health risks associated with an event and ways for individuals to protect themselves and their families. The health department plans to use the results of this study to tailor heat, drought, and flooding emergency response activities to the highest risk populations in each county.

An active surveillance program will also be developed to collect health data on clients of cooling centers and emergency shelters. Example datasets to be collected may include Injuries, Dermatologic, Gastrointestinal Illness, Pregnancy, Respiratory Illness, Pain, Dehydration, Fever, Exacerbation of Chronic Disease, and Mental Health. Furthermore, the health department will work with the Green River Area Development District to incorporate the results of the study into the upcoming revision of the regional hazard mitigation plan.

Finally, the study results have been distributed as an addendum to the 2015 Green River Community Health Assessment (CHA), Climate and Health Addendum to 2015 Green River Community Health Assessment (http://healthdepartment.org/community-health/community-health-plans/). The report's focus on vulnerable populations aligns with the goals of the CHA. Many of the populations identified by the climate and health scientific literature as vulnerable to extreme heat, drought, and/or flooding have also been identified in the $\mathrm{CHA}$ as requiring special consideration under other health-promoting programs. For example, the 2015 CHA tracks the percentage of children, elderly, non-Hispanic Blacks, and populations living in poverty for each county in the Green River District. Additionally, mental health concerns and language barriers are highlighted as areas in need of improvement to advance community health. The assessment also highlights three Kentucky Health Now Goals that overlap with the climate and health indicators listed in Table 1: obesity, cardiovascular disease, and mental health [117]. Local communities utilize the health assessment to establish priorities and develop strategic planning efforts to improve the health and resiliency of their community. The most recent CHA, published in 2015, focuses on reducing substance abuse, reducing obesity, reducing teen pregnancy, and improving access to health care and mental health services. The climate and health addendum will facilitate conversations about the links between climate change and environmental health during the next planning process, due to begin in 2017.

4.1. Strengths and Limitations. The project reviewed in this article addressed a gap in both climate and health research and practice, namely, the shortage of vulnerability assessments in rural areas [4, p. 340]. Its focus on developing EPH indicators at the local level is also rare. Two examples at that spatial scale, Reid et al. 2009 [118] and Prudent et al. 2016 [119], developed composite climate change vulnerability indices based on a core set of indicators. Importantly, these indices were mapped to subcounty spatial scales to help local authorities and partners pinpoint the locations within counties where multiple vulnerabilities converge. This information can be used to target investment in adaptation and emergency response efforts.

Due to schedule, resource, and capacity constraints, the phase of the project reviewed by this article did not include the mapping, spatial analysis, and statistical validation performed by Reid et al. and Prudent et al. That additional step is necessary to identify the subgroups and specific locations at highest risk of negative health effects after exposure to 
extreme heat, drought, and/or flooding. However, additional quantitative analysis and validation were identified in the project report as important objectives pending future funding opportunities.

The final product may bear resemblance to a localized version of the output of several grantees under the CDC's Climate Ready States and Cities program, which have followed the BRACE framework for climate and health adaptation. For example, Arizona has developed maps of social vulnerability, impervious surface, weather-related, and county warning area indicators to identify the locations in the state that are most vulnerable to negative health outcomes during extreme heat events (http://www.azdhs.gov/preparedness/epidemiology-disease-control/extreme-weather/ index.php\#heat-maps). Illinois has developed geospatial indices at the county level for social vulnerability, flooding vulnerability, and the effects of ozone on asthma vulnerability (https://braceillinois.uic.edu/). And the Minnesota Department of Health has included climate-related environmental health and human health indicators (such as air quality, asthma, chronic obstructive pulmonary disease, diabetes, heat-related illness, and Lyme disease) in its overall data access portal (https://apps.health.state.mn.us/ mndata/home).

\section{Conclusions}

Climate change represents a significant and growing threat to population health. Rural areas, such as the Green River District in Kentucky, face unique challenges that are often overlooked by climate and health policies and programs. This project addressed that gap by adapting the National Environmental Public Health Tracking Network's framework for climate and health indicators to a seven-county, rural health department in Western Kentucky.

A review of the public health literature identified three primary climate-related environmental public health hazards for the region (extreme heat, drought, and flooding) and a suite of related exposure, health outcome, population vulnerability, and environmental vulnerability indicators. Indicators that performed more poorly at the county level than at the state and national levels were defined as "high vulnerability." The most urban county, Daviess, illustrated the urban/rural divide in relation to vulnerable populations-for example, identifying homeless populations and populations with mental illness as highly vulnerable groups in comparison with outdoor workers and populations with existing chronic conditions, as seen in the more rural counties.

The health department plans to use the results of this study to enhance three key areas of their existing services: epidemiology, public health preparedness, and community health assessment.

\section{Competing Interests}

The authors declare that they have no competing interests.

\section{Acknowledgments}

This study was funded through a generous grant from the Kentucky Department for Public Health EnviroHealthLink, Kentucky's Environmental Public Health Tracking Network. A special thank you is due to the following individuals and institutions who provided data and subject matter expertise: Janie Cambron, RS, BS, MPH, and Benjamin Scott, Environmental Public Health Tracking Network, Kentucky Department for Public Health; Stuart A. Foster, Ph.D., Commonwealth Climatologist for Kentucky, Kentucky Climate Center, Department of Geography and Geology, Western Kentucky University; Sara Robeson, MA, MSPH, Division of Epidemiology and Health Planning, Kentucky Department for Public Health; and Michael Singleton, Ph.D., Kentucky Injury Prevention and Research Center, University of Kentucky College of Public Health.

\section{References}

[1] A. Crimmins, J. Balbus, J. L. Gamble et al., "Executive summary," in The Impacts of Climate Change on Human Health in the United States: A Scientific Assessment, pp. 1-24, U.S. Global Change Research Program, Washington, DC, USA, 2016.

[2] G. Luber and M. McGeehin, "Climate change and extreme heat events," American Journal of Preventive Medicine, vol. 35, no. 5, pp. 429-435, 2008.

[3] J. M. Balbus, A. Crimmins, J. L. Ch, and J. L. Gamble, "Chapter 1: introduction: climate change and human health," in Climate Change and Human Health. The Impacts of Climate Change on Human Health in the United States: A Scientific Assessment, pp. 25-42, U.S. Global Change Research Program, Washington, DC, USA, 2016.

[4] D. Hales, W. Hohenstein, M. D. Bidwell et al., "Chapter 14: rural communities. Climate change impacts in the United States: the third national climate assessment," in Climate Change Impacts in the United States, J. Melillo, T. Richmond, and G. Yohe, Eds., pp. 333-349, 2014.

[5] A. M. Isserman, E. Feser, and D. E. Warren, "Why some rural places prosper and others do not," International Regional Science Review, vol. 32, no. 3, pp. 300-342, 2009.

[6] P. Lal, J. R. R. Alavalapati, and E. D. Mercer, "Socio-economic impacts of climate change on rural United States," Mitigation and Adaptation Strategies for Global Change, vol. 16, no. 7, pp. 819-844, 2011.

[7] B. C. McDonald, D. R. Gentner, A. H. Goldstein, and R. A. Harley, "Long-term trends in motor vehicle emissions in U.S. urban areas," Environmental Science and Technology, vol. 47, no. 17, pp. 10022-10031, 2013.

[8] L. Zhang, D. J. Jacob, X. Yue, N. V. Downey, D. A. Wood, and D. Blewitt, "Sources contributing to background surface ozone in the US Intermountain West," Atmospheric Chemistry and Physics, vol. 14, no. 11, pp. 5295-5309, 2014.

[9] N. Fann, T. Brennan, P. Dolwick et al., "Air quality impacts," in The Impacts of Climate Change on Human Health in the United States: A Scientific Assessment, chapter 3, pp. 69-98, U.S. Global Change Research Program, Washington, DC, USA, 2016.

[10] C. B. Beard, R. J. Eisen, C. M. Barker et al., "Vectorborne diseases," in The Impacts of Climate Change on Human Health 
in the United States: A Scientific Assessment, chapter 5, pp. 129156, U.S. Global Change Research Program, Washington, DC, USA, 2016.

[11] S. C. Weaver and W. K. Reisen, "Present and future arboviral threats," Antiviral Research, vol. 85, no. 2, pp. 328-345, 2010.

[12] L. Eisen, B. J. Beaty, A. C. Morrison, and T. W. Scott, "Proactive vector control strategies and improved monitoring and evaluation practices for dengue prevention," Journal of Medical Entomology, vol. 46, no. 6, pp. 1245-1255, 2009.

[13] J. E. Bell, S. C. Herring, L. Jantarasami et al., "Impacts of extreme events on human health," in The Impacts of Climate Change on Human Health in the United States: A Scientific Assessment, chapter 4, pp. 99-128, U.S. Global Change Research Program, Washington, DC, USA, 2016.

[14] E. G. Hanna and P. W. Tait, "Limitations to thermoregulation and acclimatization challenge human adaptation to global warming," International Journal of Environmental Research and Public Health, vol. 12, no. 7, pp. 8034-8074, 2015.

[15] J. Berko, D. D. Ingram, S. Saha, and J. D. Parker, "Deaths attributed to heat, cold, and other weather events in the United States, 2006-2010," National Health Statistics Reports, vol. 2014, no. 76, pp. 1-15, 2014.

[16] K. Knowlton, M. Rotkin-Ellman, G. King et al., "The 2006 California heat wave: impacts on hospitalizations and emergency department visits," Environmental Health Perspectives, vol. 117, no. 1, pp. 61-67, 2009.

[17] R. Basu and J. M. Samet, "Relation between elevated ambient temperature and mortality: a review of the epidemiologic evidence," Epidemiologic Reviews, vol. 24, no. 2, pp. 190-202, 2002.

[18] B. G. Anderson and M. L. Bell, "Weather-related mortality: how heat, cold, and heat waves affect mortality in the United States," Epidemiology, vol. 20, no. 2, pp. 205-213, 2009.

[19] J. M. Balbus and C. Malina, "Identifying vulnerable subpopulations for climate change health effects in the United States," Journal of Occupational and Environmental Medicine, vol. 51, no. 1, pp. 33-37, 2009.

[20] C. K. Uejio, O. V. Wilhelmi, J. S. Golden, D. M. Mills, S. P. Gulino, and J. P. Samenow, "Intra-urban societal vulnerability to extreme heat: the role of heat exposure and the built environment, socioeconomics, and neighborhood stability," Health and Place, vol. 17, no. 2, pp. 498-507, 2011.

[21] C. J. Gronlund, "Racial and socioeconomic disparities in heatrelated health effects and their mechanisms: a review," Current Epidemiology Reports, vol. 1, no. 3, pp. 165-173, 2014.

[22] M. S. O’Neill, A. Zanobetti, and J. Schwartz, "Disparities by race in heat-related mortality in four US cities: the role of air conditioning prevalence," Journal of Urban Health, vol. 82, no. 2, pp. 191-197, 2005.

[23] M. Medina-Ramón and J. Schwartz, "Temperature, temperature extremes, and mortality: a study of acclimatisation and effect modification in 50 US cities," Occupational and Environmental Medicine, vol. 64, no. 12, pp. 827-833, 2007.

[24] K. Lane, K. Charles-Guzman, K. Wheeler, Z. Abid, N. Graber, and T. Matte, "Health effects of coastal storms and flooding in urban areas: a review and vulnerability assessment," Journal of Environmental and Public Health, vol. 2013, Article ID 913064, 13 pages, 2013.

[25] D. Lowe, K. L. Ebi, and B. Forsberg, "Factors increasing vulnerability to health effects before, during and after floods," International Journal of Environmental Research and Public Health, vol. 10, no. 12, pp. 7015-7067, 2013.
[26] L. J. Akinbami, J. E. Moorman, C. Bailey et al., "Trends in asthma prevalence, health care use, and mortality in the United States, 2001-2010," NCHS Data Brief, no. 94, pp. 1-8, 2012.

[27] G. Adamkiewicz, A. R. Zota, M. Patricia Fabian et al., "Moving environmental justice indoors: understanding structural influences on residential exposure patterns in low-income communities," American Journal of Public Health, vol. 101, no. 1, pp. S238-S245, 2011.

[28] B. T. Kitch, G. Chew, H. A. Burge et al., "Socioeconomic predictors of high allergen levels in homes in the greater Boston area," Environmental Health Perspectives, vol. 108, no. 4, pp. 301$307,2000$.

[29] C. Klinger, O. Landeg, and V. Murray, "Power outages, extreme events and health: a systematic review of the literature from 2011-2012," PLoS Currents, 2014.

[30] G. B. Anderson and M. L. Bell, "Lights out: impact of the August 2003 power outage on mortality in New York, NY," Epidemiology, vol. 23, no. 2, pp. 189-193, 2012.

[31] C. A. Jones, T. S. Parker, M. Ahearn, A. K. Mishra, and J. N. Variyam, "Health status and health care access of farm and rural populations," Tech. Rep. EIB-57, 2009.

[32] J. L. Gamble, J. Balbus, M. Berger et al., "Populations of concern," in The Impacts of Climate Change on Human Health in the United States: A Scientific Assessment, chapter 9, pp. 247286, U.S. Global Change Research Program, Washington, DC, USA, 2016.

[33] J. Hatfield, G. Takle, R. Grotjahn et al., "Chapter 6: agriculture," in Climate Change Impacts in the United States: The Third National Climate Assessment, J. Melillo, T. Richmond, and G. Yohe, Eds., pp. 150-174, 2014.

[34] U.S. Environmental Protection Agency, Inventory of U.S. Greenhouse Gas Emissions and Sinks: 1990-2014, 2016.

[35] J. L. Hatfield, K. J. Boote, B. A. Kimball et al., "Climate impacts on agriculture: implications for crop production," Agronomy Journal, vol. 103, no. 2, pp. 351-370, 2011.

[36] C. L. Walthall, J. Hatfield, P. Backlund et al., "Climate change and agriculture in the United States: effects and adaptation," USDA Technical Bulletin 1935, 2012.

[37] S. C. Sheridan and T. J. Dolney, "Heat, mortality, and level of urbanization: measuring vulnerability across Ohio, USA," Climate Research, vol. 24, no. 3, pp. 255-265, 2003.

[38] E. W. Maibach, A. Chadwick, D. McBride, M. Chuk, K. L. Ebi, and J. Balbus, "Climate change and local public health in the United States: preparedness, programs and perceptions of local public health department directors," PLoS ONE, vol. 3, no. 7, 2008.

[39] H. Frumkin, J. Hess, G. Luber, J. Malilay, and M. McGeehin, "Climate change: the public health response," American Journal of Public Health, vol. 98, no. 3, pp. 435-445, 2008.

[40] A. Crimmins, J. Balbus, J. L. Gamble et al., Eds., U.S. Global Change Research Program (USGCRP) The Impacts of Climate Change on Human Health in the United States: A Scientific Assessment, Washington, DC, USA, 2016.

[41] M. A. McGeehin, J. R. Qualters, and A. Sue Niskar, "National environmental public health tracking program: bridging the information gap," Environmental Health Perspectives, vol. 112, no. 14, pp. 1409-1413, 2004.

[42] Kentucky Department of Public Health Kentucky Environmental Public Health Tracking, http://chfs.ky.gov/dph/info/phps/ epht.htm. 
[43] US Centers for Disease Control and Prevention National Environmental Public Health Tracking, Funded Programs and Contacts, https://www.cdc.gov/nceh/tracking/projects/home.htm.

[44] Census Bureau, http://www.census.gov/.

[45] G. D. Marinucci, G. Luber, C. K. Uejio, S. Saha, and J. J. Hess, "Building resilience against climate effects-a novel framework to facilitate climate readiness in public health agencies," International Journal of Environmental Research and Public Health, vol. 11, no. 6, pp. 6433-6458, 2014.

[46] M. J. Melillo, T. C. Richmond, and G. W. Yohe, Eds., Climate Change Impacts in the United States: The Third National Climate Assessment, U.S. Global Change Research Program, Washington, DC, USA, 2014.

[47] "Kentucky Department of Fish and Wildlife Resources Action Plan to Respond to Climate Change in Kentucky: a strategy of resilience," in Kentucky's Comprehensive Wildlife Conservation Strategy, Kentucky Department of Fish and Wildlife Resources, \#1 Sportsman's Lane, Frankfort, Ky, USA, 2013.

[48] Green River Area Development District, "GRADD Hazard Mitigation Plan: 2016 Update," 2016.

[49] U.S. Federal Emergency Management Agency (FEMA), "Disaster Declarations," https://www.fema.gov/disasters.

[50] National Oceanic and Atmospheric Administration National Climatic Data Center Storm Events Database, http://www.ncdc .noaa.gov/stormevents.

[51] F. Kinniburgh, M. G. Simonton, and C. Allouch, Come Heat and High Water: Climate Risk in the Southeastern US and Texas, Risky Business: The Bottom Line on Climate Change, 2015.

[52] M. C. Sarofim, S. Saha, M. D. Hawkins, and D. M. Mills, "Chapter 2: temperature-related death and illness," in The Impacts of Climate Change on Human Health in the United States: A Scientific Assessment, pp. 43-68, US Global Change Research Program, Washington, DC, USA, 2016.

[53] H. L. Berry, K. Bowen, and T. Kjellstrom, "Climate change and mental health: a causal pathways framework," International Journal of Public Health, vol. 55, no. 2, pp. 123-132, 2010.

[54] H. L. Berry, B. J. Kelly, I. C. Hanigan et al., "Rural mental health impacts of climate change," Garnaut Climate Change Review, p. 40, 2008.

[55] A. Hansen, P. Bi, M. Nitschke, P. Ryan, D. Pisaniello, and G. Tucker, "The effect of heat waves on mental health in a temperate Australian City," Environmental Health Perspectives, vol. 116, no. 10, pp. 1369-1375, 2008.

[56] S. Vida, M. Durocher, T. B. M. J. Ouarda, and P. Gosselin, "Relationship between ambient temperature and humidity and visits to mental health emergency departments in québec," Psychiatric Services, vol. 63, no. 11, pp. 1150-1153, 2012.

[57] CDC, Extreme Heat and Your Health: Heat and Infants and Children, Centers for Disease Control and Prevention, 2011, http://www.cdc.gov/extremeheat/children.html.

[58] A. Hansen, L. Bi, A. Saniotis, and M. Nitschke, "Vulnerability to extreme heat and climate change: is ethnicity a factor?" Global Health Action, vol. 6, no. 1, Article ID 21364, 2013.

[59] B. Ramin and T. Svoboda, "Health of the homeless and climate change," Journal of Urban Health, vol. 86, no. 4, pp. 654-664, 2009.

[60] S. Arbury, B. Jacklitsch, O. Farquah et al., "Heat illness and death among workers-United States, 2012-2013," Morbidity and Mortality Weekly Report, vol. 63, no. 31, pp. 661-665, 2014.

[61] K. Lundgren, K. Kuklane, C. Gao, and I. Holmér, "Effects of heat stress on working populations when facing climate change," Industrial Health, vol. 51, no. 1, pp. 3-15, 2013.
[62] U.S. Environmental Protection Agency, "Climate change indicators in the United States," EPA 430-R-10-007, U.S. Environmental Protection Agency, Washington, DC, USA, 2010.

[63] P. Y. Groisman, T. R. Karl, D. R. Easterling et al., "Changes in the probability of heavy precipitation: important indicators of climatic change," Climatic Change, vol. 42, no. 1, pp. 243-283, 1999.

[64] T. R. Karl and R. W. Knight, "Secular trends of precipitation amount, frequency, and intensity in the United States," Bulletin of the American Meteorological Society, vol. 79, no. 2, pp. 231-241, 1998.

[65] "Climate Central States at Risk: America's Preparedness Report Card-Kentucky," 2016, http://statesatrisk.org/report-card/ kentucky.

[66] C. Stanke, M. Kerac, C. Prudhomme, J. Medlock, and V. Murray, "Health effects of drought: a systematic review of the evidence," PLOS Currents Disasters, 2013.

[67] Centers for Disease Control and Prevention, U.S. Environmental Protection Agency, National Oceanic and Atmospheric Agency, and American Water Works Association, When Every Drop Counts: Protecting Public Health During Drought Conditions-A Guide for Public Health Professional, CDC, Atlanta, Ga, USA, 2010.

[68] K. A. Reynolds, K. D. Mena, and C. P. Gerba, "Risk of waterborne illness via drinking water in the United States," Reviews of Environmental Contamination and Toxicology, vol. 192, pp. 117-158, 2008.

[69] Z. Xu, P. E. Sheffield, W. Hu et al., "Climate change and children's health-a call for research on what works to protect children," International Journal of Environmental Research and Public Health, vol. 9, no. 9, pp. 3298-3316, 2012.

[70] A. S. Bernstein and S. S. Myers, "Climate change and children's health," Current Opinion in Pediatrics, vol. 23, no. 2, pp. 221-226, 2011.

[71] E. J. Kistin, J. Fogarty, R. S. Pokrasso, M. McCally, and P. G. McCornick, "Climate change, water resources and child health," Archives of Disease in Childhood, vol. 95, no. 7, pp. 545-549, 2010.

[72] B. A. Lopman, A. J. Hall, A. T. Curns, and U. D. Parashar, "Increasing rates of gastroenteritis hospital discharges in US adults and the contribution of norovirus, 1996-2007," Clinical Infectious Diseases, vol. 52, no. 4, pp. 466-474, 2011.

[73] J. L. Peel, K. B. Metzger, M. Klein, W. D. Flanders, J. A. Mulholland, and P. E. Tolbert, "Ambient air pollution and cardiovascular emergency department visits in potentially sensitive groups," American Journal of Epidemiology, vol. 165, no. 6, pp. 625-633, 2007.

[74] J. C. Fritze, G. A. Blashki, S. Burke, and J. Wiseman, "Hope, despair and transformation: climate change and the promotion of mental health and wellbeing," International Journal of Mental Health Systems, vol. 2, article no. 13, 2008.

[75] L. V. OBrien, H. L. Berry, C. Coleman, and I. C. Hanigan, "Drought as a mental health exposure," Environmental Research, vol. 131, pp. 181-187, 2014.

[76] T.-L. Carnie, H. L. Berry, S. A. Blinkhorn, and C. R. Hart, "In their own words: young people's mental health in droughtaffected rural and remote NSW," Australian Journal of Rural Health, vol. 19, no. 5, pp. 244-248, 2011.

[77] I. C. Hanigan, C. D. Butler, P. N. Kokic, and M. F. Hutchinson, "Suicide and drought in New South Wales, Australia, 19702007," Proceedings of the National Academy of Sciences of the United States of America, vol. 109, no. 35, pp. 13950-13955, 2012. 
[78] Federal Emergency Management Agency, Department of Homeland Security Declared Disasters by Year or State, 2011, https://www.fema.gov/disasters.

[79] Kentucky Climate Center Climate Change: Summary of Kentucky Temperature and Precipitation Trends, http://www.kyclimate.org/graphlets/climatechange.html.

[80] "Western Kentucky University Department of Geography and Geology Kentucky Climate Center," 2016, http://www.kyclimate .org/.

[81] W. Du, G. FitzGerald, M. Clark, and X. Hou, "Health impacts of floods," Prehospital and Disaster Medicine, vol. 25, no. 3, pp. 265-272, 2010.

[82] D. M. M. Kellar and T. W. Schmidlin, "Vehicle-related flood deaths in the United States, 1995-2005," Journal of Flood Risk Management, vol. 5, no. 2, pp. 153-163, 2012.

[83] H. O. Sharif, T. L. Jackson, M. M. Hossain, and D. Zane, "Analysis of flood fatalities in texas," Natural Hazards Review, vol. 16, no. 1, 2015.

[84] M. Špitalar, J. J. Gourley, C. Lutoff, P.-E. Kirstetter, M. Brilly, and N. Carr, "Analysis of flash flood parameters and human impacts in the US from 2006 to 2012," Journal of Hydrology, vol. 519, pp. 863-870, 2014.

[85] K. Alderman, L. R. Turner, and S. Tong, "Floods and human health: a systematic review," Environment International, vol. 47, pp. 37-47, 2012.

[86] W. Du, G. J. FitzGerald, M. Clark, and X.-Y. Hou, "Health impacts of floods," Prehospital and Disaster Medicine, vol. 25, pp. 265-272, 2010.

[87] D. Mudarri and W. J. Fisk, "Public health and economic impact of dampness and mold," Indoor Air, vol. 17, no. 3, pp. 226-235, 2007.

[88] W. J. Fisk, E. A. Eliseeva, and M. J. Mendell, "Association of residential dampness and mold with respiratory tract infections and bronchitis: a meta-analysis," Environmental Health, vol. 9, no. 1, article no. 72, 2010.

[89] W. W. Nazaroff, "Exploring the consequences of climate change for indoor air quality, Environmental Research Letters, vol. 8, no. 1, 2013.

[90] T. Waite, V. Murray, and D. Baker, "Carbon monoxide poisoning and flooding: changes in risk before, during and after flooding require appropriate public health interventions," PLoS Currents Disasters, 2014.

[91] L. Peek and L. M. Stough, "Children with disabilities in the context of disaster: a social vulnerability perspective," Child Development, vol. 81, no. 4, pp. 1260-1270, 2010.

[92] M. A. Brandenburg, S. M. Watkins, K. L. Brandenburg, and C. Schieche, "Operation Child-ID: reunifying children with their legal guardians after Hurricane Katrina," Disasters, vol. 31, no. 3, pp. 277-287, 2007.

[93] D. S. K. Thomas, B. D. Phillips, W. E. Lovekamp, and A. Fothergill, Eds., Social Vulnerability to Disasters, CRC Press, 2nd edition, 2013.

[94] R. Guenther and J. Balbus, Primary Protection: Enhancing Health Care Resilience for a Changing Climate, 2014.

[95] M. I. Arrieta, R. D. Foreman, E. D. Crook, and M. L. Icenogle, "Providing continuity of care for chronic diseases in the aftermath of Katrina: from field experience to policy recommendations," Disaster Medicine and Public Health Preparedness, vol. 3, no. 3, pp. 174-182, 2009.

[96] S. B. Laditka, J. N. Laditka, S. Xirasagar, C. B. Cornman, C. B. Davis, and J. V. E. Richter, "Providing shelter to nursing home evacuees in disasters: lessons from Hurricane Katrina," American Journal of Public Health, vol. 98, no. 7, pp. 1288-1293, 2008.

[97] D. E. Battle, "Persons with communication disabilities in natural disasters, war, and/or conflict," Communication Disorders Quarterly, vol. 36, no. 4, pp. 231-240, 2015.

[98] D. P. Andrulis, N. J. Siddiqui, and J. L. Gantner, "Preparing racially and ethnically diverse communities for public health emergencies," Health Affairs, vol. 26, no. 5, pp. 1269-1279, 2007.

[99] A. L. Lippmann, "Disaster preparedness in vulnerable communities," International Law and Policy Review, vol. 1, pp. 69-96, 2011.

[100] N. Aldrich and W. F. Benson, "Disaster preparedness and the chronic disease needs of vulnerable older adults," Preventing Chronic Disease, vol. 5, no. 1, 2008.

[101] A. H. Mokdad, G. A. Mensah, S. F. Posner et al., "When chronic conditions become acute: prevention and control of chronic diseases and adverse health outcomes during natural disasters," Preventing Chronic Disease, vol. 2, article no. A04, 2005.

[102] "U.S. Centers for Disease Control and Prevention heat-related mortality-Chicago," Morbidity and Mortality Weekly Report, vol. 44, pp. 577-579, 1995.

[103] J. C. Semenza, J. E. McCullough, W. D. Flanders, M. A. McGeehin, and J. R. Lumpkin, "Excess hospital admissions during the July 1995 heat wave in Chicago," American Journal of Preventive Medicine, vol. 16, no. 4, pp. 269-277, 1999.

[104] C. E. Reid, J. K. Mann, R. Alfasso et al., "Evaluation of a heat vulnerability index on abnormally hot days: An Environmental Public Health Tracking Study," Environmental Health Perspectives, vol. 120, no. 5, pp. 715-720, 2012.

[105] D. Oudin Åström, F. Bertil, and R. Joacim, "Heat wave impact on morbidity and mortality in the elderly population: a review of recent studies," Maturitas, vol. 69, no. 2, pp. 99-105, 2011.

[106] U.S. Centers for Disease Control and Prevention, National Environmental Public Health Tracking Network, http://ephtracking .cdc.gov/.

[107] "U.S. Environmental Protection Agency National Ambient Air Quality Standards Table," https://www.epa.gov/criteria-airpollutants/naaqs-table.

[108] "U.S. Department of Health and Human Services Office of Disease Prevention and Health Promotion Nutrition and Weight Status," https://www.healthypeople.gov/2020/topicsobjectives/topic/nutrition-and-weight-status/objectives.

[109] U.S. Department of Health and Human Services Office of Disease Prevention and Health Promotion, Heart Disease and Stroke. Healthy People 2020 Topics and Objectives, https:// www.healthypeople.gov/2020/topics-objectives/topic/heartdisease-and-stroke.

[110] U.S. Department of Health and Human Services and Office of Disease Prevention and Health Promotion, "Respiratory Diseases," Healthy People 2020 Topics and Objectives, https:// www.healthypeople.gov/2020/topics-objectives/topic/respiratory-diseases.

[111] "U.S. Centers for Disease Control and Prevention WONDER," 2016, http://wonder.cdc.gov/.

[112] K. Knowlton, Climate Change Threatens Health, http://www .nrdc.org/health/climate/.

[113] U.S. Federal Emergency Management Agency National Flood Insurance Program Policy Statistics Country-Wide as of 04/30/ 2016 2016, http://bsa.nfipstat.fema.gov/reports/1011.htm\#KYT. 
[114] "Kentucky Department for Public Health Cabinet for Health and Family Services Kentucky Death Certificates Files," Frankfort, Ky, USA, 2008-2015.

[115] Kentucky Cabinet for Health and Family Services Office of Health Policy Unintentional Carbon Monoxide Poisoning Emergency Department Data, 2008-2013, 2015, EnviroHealthLink June 2016.

[116] Revised Table of Reportable Diseases and Conditions in Kentucky; United States, 2016.

[117] Green River District Health Department, Green River Community Health Assessment, 2015.

[118] C. E. Reid, M. S. O’Neill, C. J. Gronlund et al., "Mapping community determinants of heat vulnerability," Environmental Health Perspectives, vol. 117, no. 11, pp. 1730-1736, 2009.

[119] N. Prudent, A. Houghton, and G. Luber, "Assessing climate change and health vulnerability at the local level: travis County, Texas," Disasters, vol. 40, no. 4, pp. 740-752, 2016. 


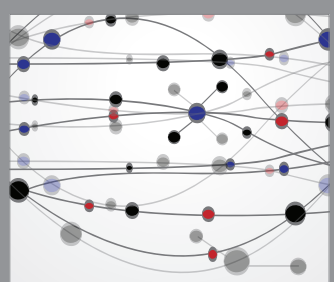

The Scientific World Journal
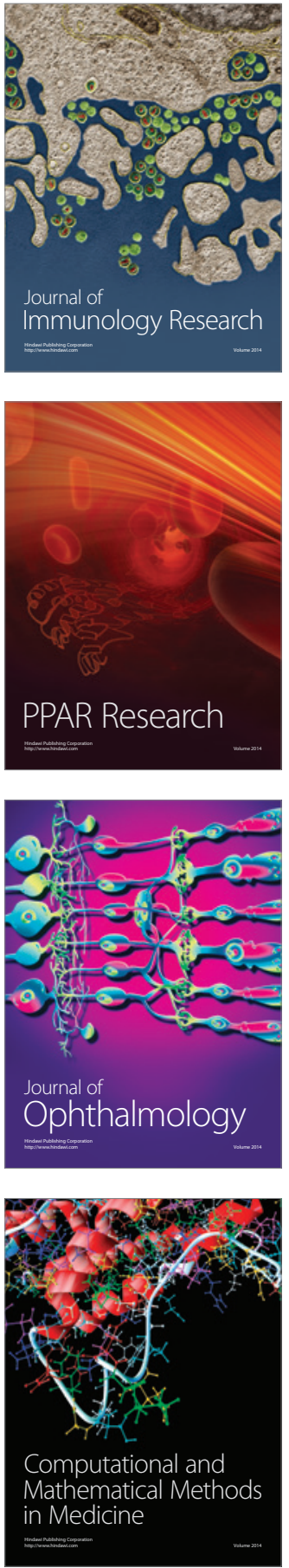

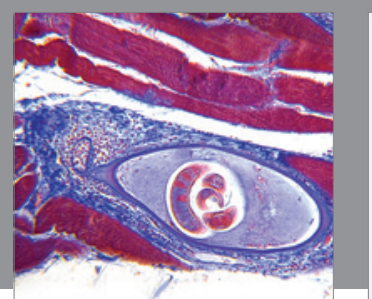

Gastroenterology Research and Practice
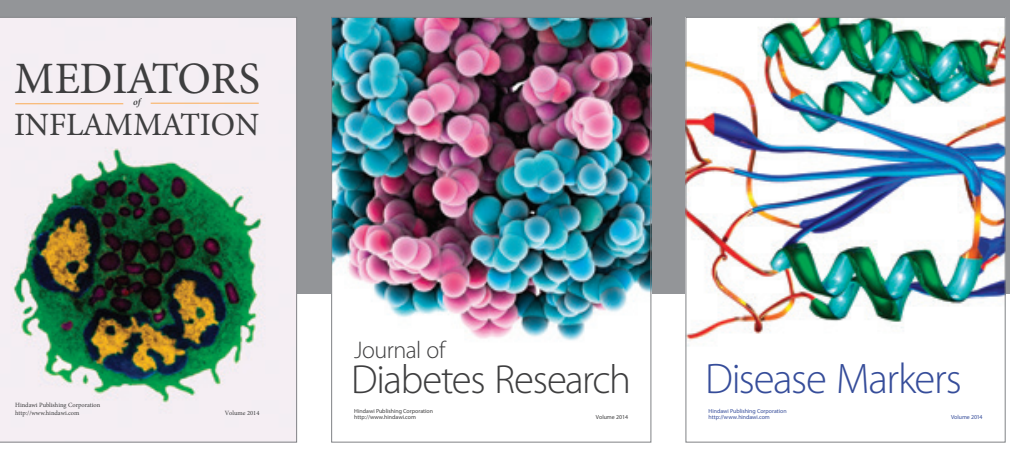

Disease Markers

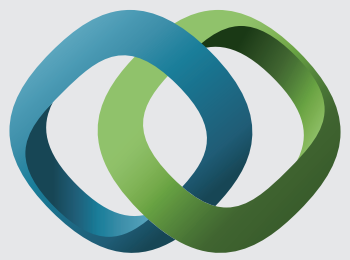

\section{Hindawi}

Submit your manuscripts at

https://www.hindawi.com
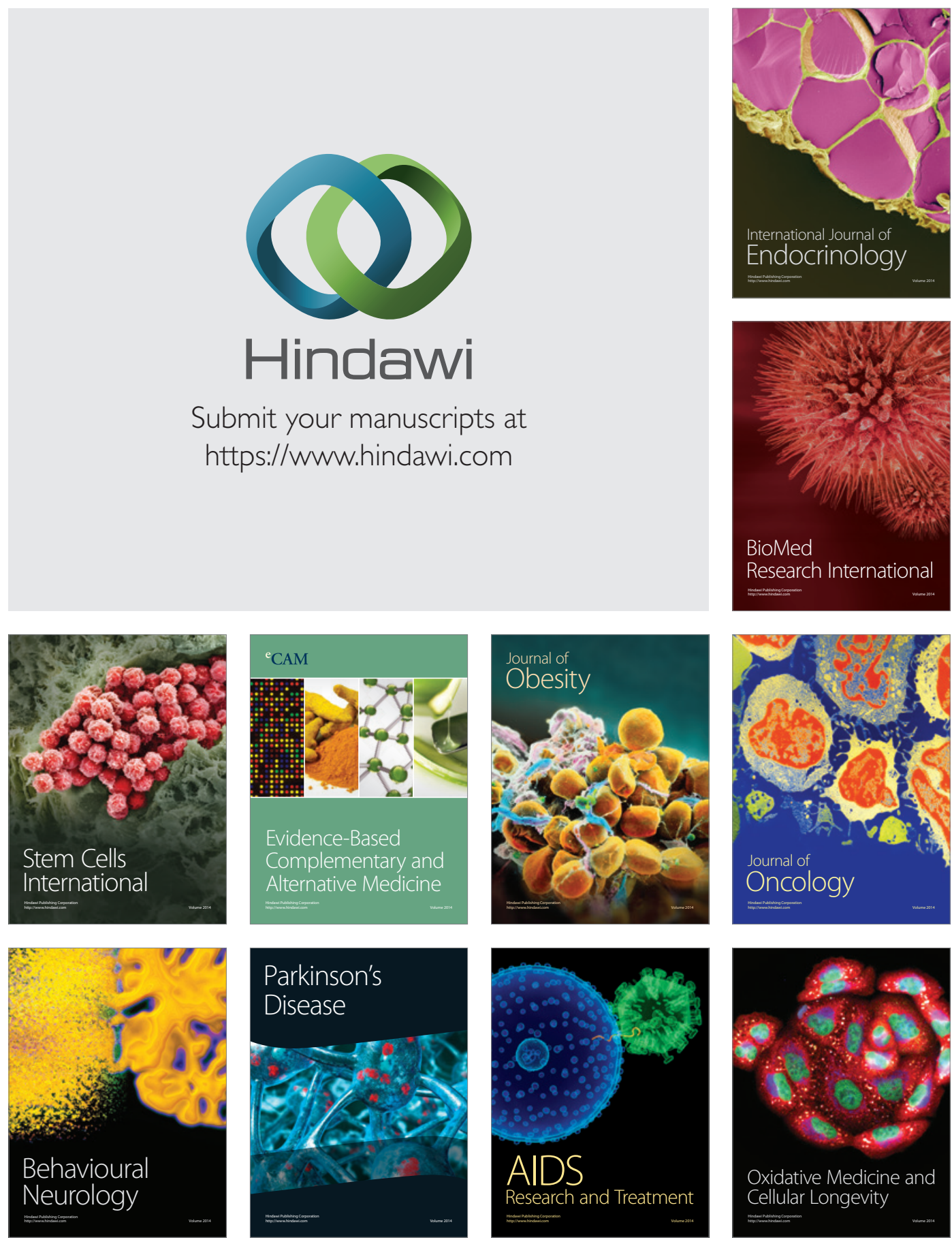